\title{
VERTICAL \& HORIZONTAL GROUND DEFORMATION OF SANTORINI ISLAND DEDUCED BY DGPS MEASUREMENTS
}

\author{
Papageorgiou E. ${ }^{1}$, Lagios E. ${ }^{1}$, Vassilopoulou S. ${ }^{1}$, and Sakkas V. ${ }^{1}$ \\ ${ }^{1}$ Department of Geophysics \& Geothermics, School of Geology and Geoenvironment, National \\ and Kapodistrian University of Athens, epapageo@geol.uoa.gr,lagios@geol.uoa.gr, \\ vassilopoulou@geol.uoa.gr,sakkas@geol.uoa.gr
}

\begin{abstract}
Santorini is considered to be a dormant volcano with fairly high geodynamic unrest. Two major tectonic NE-SW trending fault zones, Kammeni and Columbo Lines, which intersect the main part of the volcanic edifice, have affected the magma flow at relatively shallow depths enabling the appearance of individual volcanic centers on the island. GPS measurements on a network of 18 stations were carried out in 1994 and 2005 in order to estimate the ground deformation, both in vertical and horizontal component. The results show that the highest amplitude of subsidence (45 $\mathrm{mm})$ and uplift $(51 \mathrm{~mm})$ is noticed on Nea Kammeni and Cape Columbo, respectively. Considering the horizontal displacements, it appears that these sites were strongly affected by the above major faulting zones. They vary between $4 \mathrm{~mm}$ and $37 \mathrm{~mm}$, where the highest amplitudes are observed at the south-western corner of Thera and Therassia Islands. Their directions seem to correlate with the observed subsidence in the caldera (deflation) and a probable inflation around the area of the sub-marine Columbo Volcano.
\end{abstract}

Key words: geodetic network, subsidence, uplift, volcanic activity.

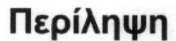

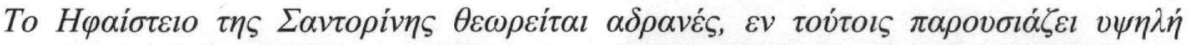
$\gamma \varepsilon \omega \delta v v \alpha \mu \imath \kappa \dot{~ \delta \rho \alpha \sigma \tau \eta \rho i ́ \tau \eta \tau \alpha . ~ O l ~ \delta v ́ o ~ \kappa v ́ \rho l \varepsilon \varsigma ~ \zeta \omega ́ v \varepsilon \varsigma ~ \delta l \alpha ́ \rho \rho \eta \xi \eta ऽ, ~ \tau \eta \varsigma ~ K \alpha \mu \mu \varepsilon ́ v \eta \varsigma ~ \kappa \alpha l ~ \tau o v ~}$

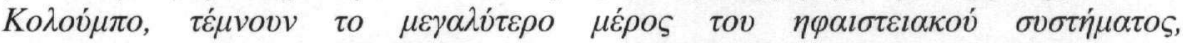

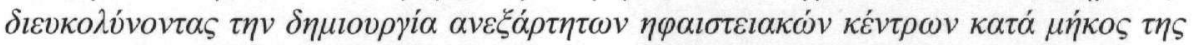

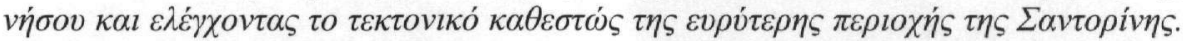

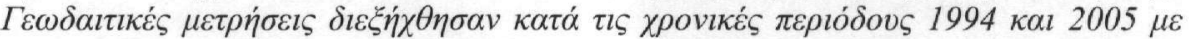

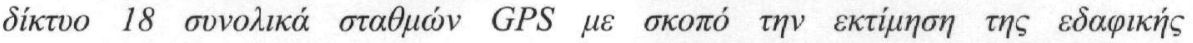

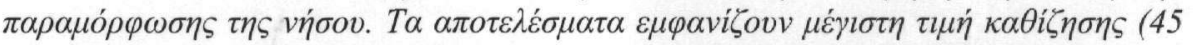

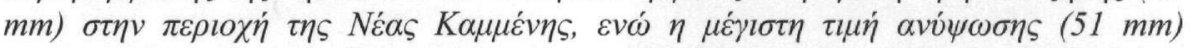

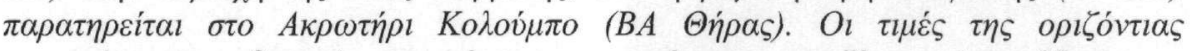

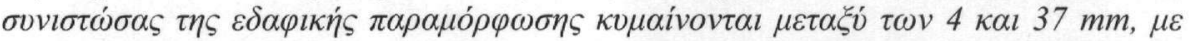

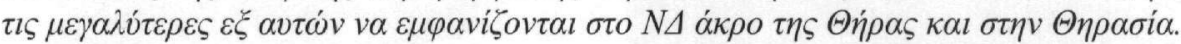

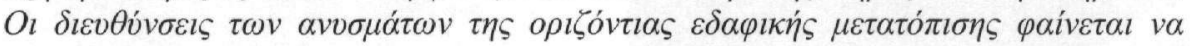

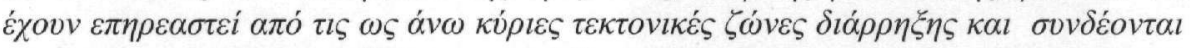

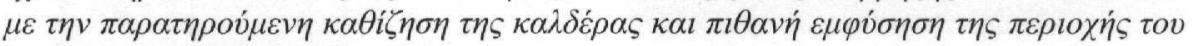

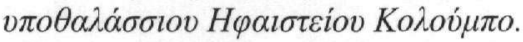

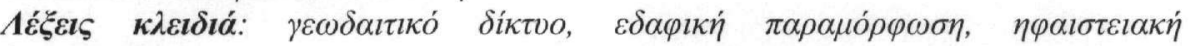

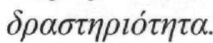




\section{Introduction}

Santorini Island, one of the largest Quaternary volcanic centers of the Aegean region, is located in the central part of the Hellenic Volcanic Arc (Fig. 1), which was developed 13 my ago (Angelier et al. 1982) as a result of the lithospheric subduction process between the African and Eurasian plates (McKenzie 1970, 1972, Papazachos and Komninakis 1971, Le Pichon and Angelier 1979). Continent to continent collision is currently in progress between the African plate and the Aegean microplate at a rate of up to $5 \mathrm{~cm} / \mathrm{yr}$, in a north-easterly direction. Santorini Volcano, among other Quaternary volcanoes of the Aegean, defines the Southern Aegean active volcanic arc in a continental environment of extensional tectonics (Jackson 1994) with earthquakes occurring at depths of $150-170 \mathrm{~km}$. The extension was initiated in the area during Upper Miocene, changing direction from WNW-ESE (Late Miocene) to NE-SW (Pliocene-Early Pleistocene), while currently is N-S to NW-SE (Mercier et al. 1989).

The Santorini volcanic complex (Thera, Therassia, Palea and Nea Kammeni) constitutes an almost circular depression up to almost $400 \mathrm{~m}$ depth. Palea and Nea Kammeni islands were formed in the middle of the caldera due to the volcanic activity which was resumed after the Minoan eruption $(\sim 3.5 \mathrm{ka}$ B.P.). The dominant tectonic lineament affecting the Santorini area has an approximate NE-SW trend, with the exception of an elongated dip $(330 \mathrm{~m})$ that separates northern Thera from Therassia and is supposed to represent either a NW-SE trending graben (Pichler and Kussmaul 1980) or the result of a rotational slumping (Heiken and McCoy 1984). The main morphotectonic features of the Santorini volcanic edifice is therefore controlled by two principal NE-SW faulting zones, called Kammeni and Columbo Lines (Fig. 2), the composite structure of the flooded caldera comprised by four flat-floored basins, and the submarine Columbo Bank volcano (last eruption 1650), located about $6.5 \mathrm{~km} \mathrm{NE}$ of the northern coast of Santorini.

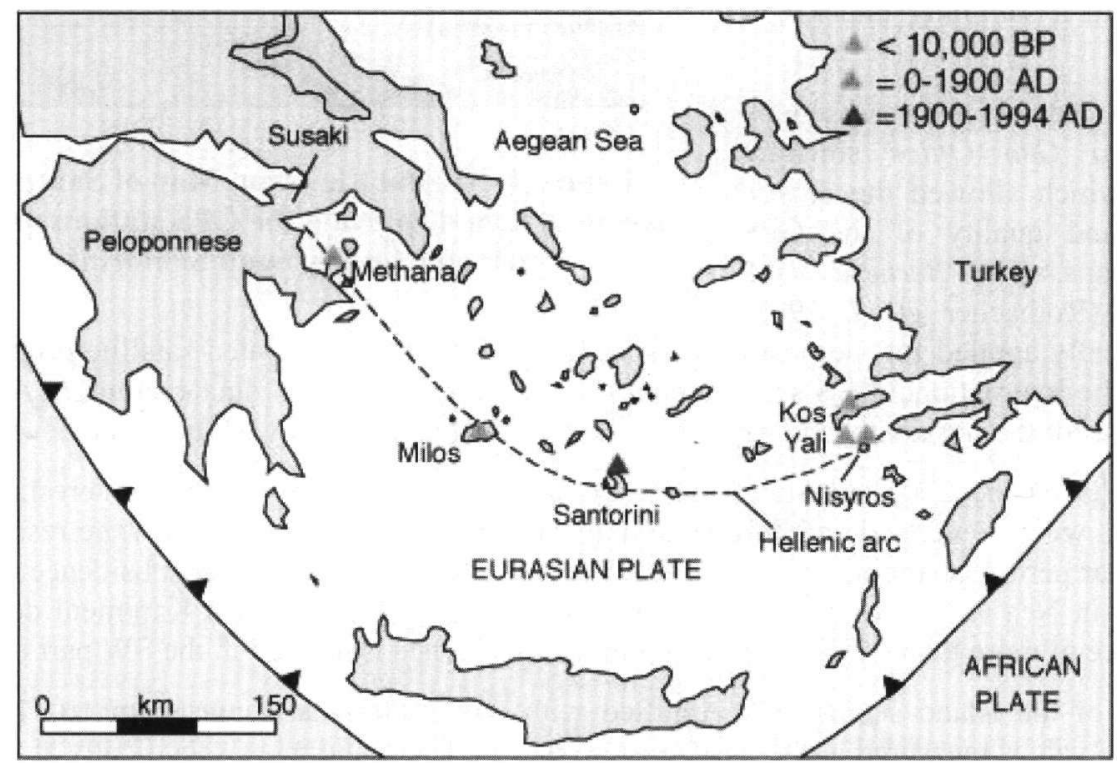

Figure 1 - Volcanic centers of the Hellenic Volcanic Arc

The Kammeni Line intersects the caldera, crossing both Palea and Nea Kammeni islets, and the Aspronisi tuff ring. The parallel tectonic line of Columbo passes through the cinder cones of Megalo Vouno, Kokkino Vouno, the Cape Columbo tuff ring, and Columbo volcano. It is clear that the existing tectonic fault zones have strongly influenced the emplacement of magma, as well as the development of the whole volcanic field (Piper et al. 2004). At present, the volcanic manifestations on Santorini consist of fumaroles and hot springs, mainly located on Nea Kammeni. 


\section{DGPS Measurements}

A GPS network consisting of 18 stations (Fig. 2) was installed in 1994 in order to study the ground deformation of Santorini Volcano (Giannopoulos et al. 1996). It was remeasured several times since then with the last one in August of 2005. Distinctly, 13 stations were established on Thera, 3 on Nea Kammeni, and 2 on Therassia.

Geodetic, dual-frequency receivers of TRIMBLE, ASHTECH and WILD type of LEICA were employed in the field campaigns. A station established near Pyrgos (No 7) was chosen as the reference station for the GPS measurement analysis. This station is lying on the pre-volcanic basement massif of the Upper Triassic limestones. The rest of the stations were used as rovers recording more than 6 hours with a sampling interval of $15 \mathrm{sec}$.

The GPS data were processed by the Leica Geo Office software (2004), which allowed the in situ control and quality of the GPS observations. The Bernese v.4.2

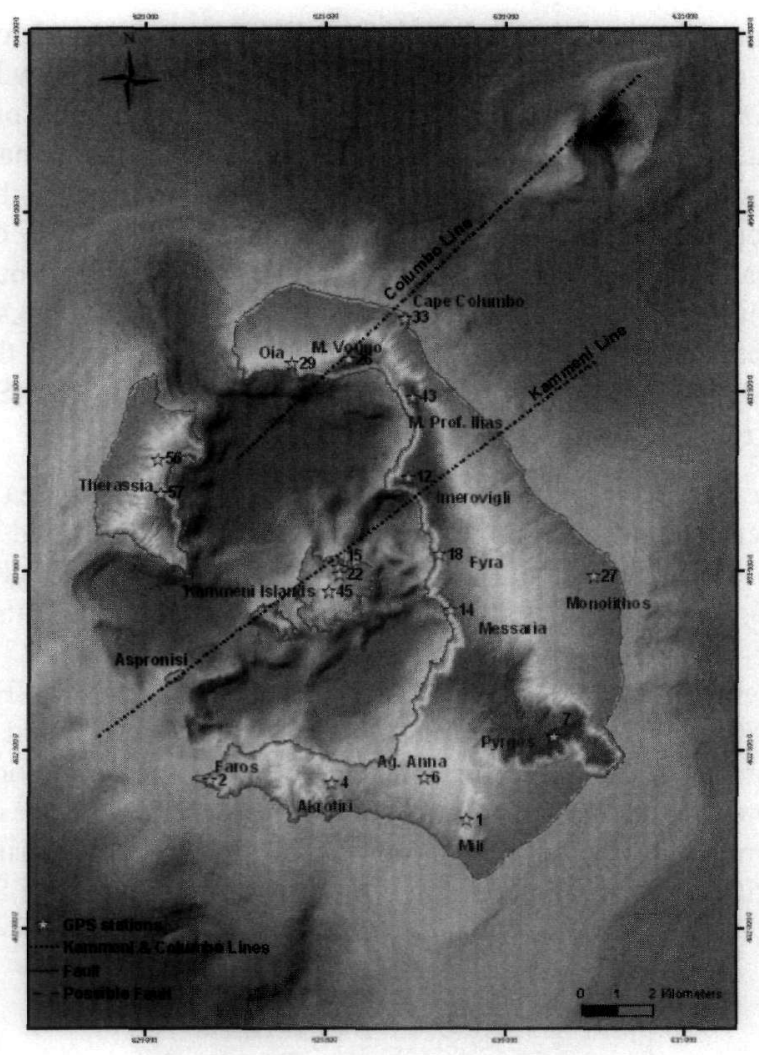

Figure 2 - Digital Elevation Map of Santorini Island system displaying the GPS stations and the tectonic lines around Santorini software (Rothacher et al. 1993) was basically applied for the post-processing of the data. Post-computed satellite orbits available through the International GPS service were used to improve the coordinate solution. An accuracy of 2-3 mm for the horizontal and 4-6 mm for the vertical component was finally achieved.

The results of the 2005 measurements were compared to those of 1994. Interesting features associated with the vertical and horizontal deformation of the island complex were resulted during the 11-year period, spanning from 1994-2005 (Fig. 3, 4). It was found that subsidence is generally observed in Nea Kammeni and at the south-western part of Thera. Nea Kammeni demonstrates subsidence of more than $45 \mathrm{~mm}$, while $20 \mathrm{~mm}$ of subsidence is noticed in the SW part of Thera.

The rest of the island seems to be uplifted with amplitudes that range from $10-51 \mathrm{~mm}$, with maximum values measured at the north-eastern part of Thera and more specifically at the location of Cape Columbo (station 33). Uplift is also observed at the two GPS stations in Therassia, ranging from 22-26 $\mathrm{mm}$ (Fig. 3).

The horizontal displacements range from 4-37 $\mathrm{mm}$ with directions generally to the NW for the majority of the stations (Fig. 4), apparently consistent with the general kinematic model of South Aegean (Mercier et al. 1989, Papazachos et al. 1996, 1998). The larger amplitudes are measured at the south-western part of Thera $(37 \mathrm{~mm})$, as well as in Therassia $(31 \mathrm{~mm})$. In the northern part of Thera the amplitudes range between 15 and $21 \mathrm{~mm}$ (No 29, 26, 33 \& 43) and have directions generally to the NW. All stations established on Thera along the caldera rim, such as No 2, 4, 6, 14 
\& 18, have directions towards the caldera. Referring to the two stations on Therassia, they both have similar directions towards the NW. However the directional picture of the stations on Nea Kammeni is not so consistent as previously in Therassia as the directions vary from W to SW.

An exception to the rule is station 18 whose horizontal component has a N-S direction. The reason is somehow owing to the fact that is located between three neighboring faults, and therefore its direction may likely be affected by the motion of the adjacent tectonic blocks.

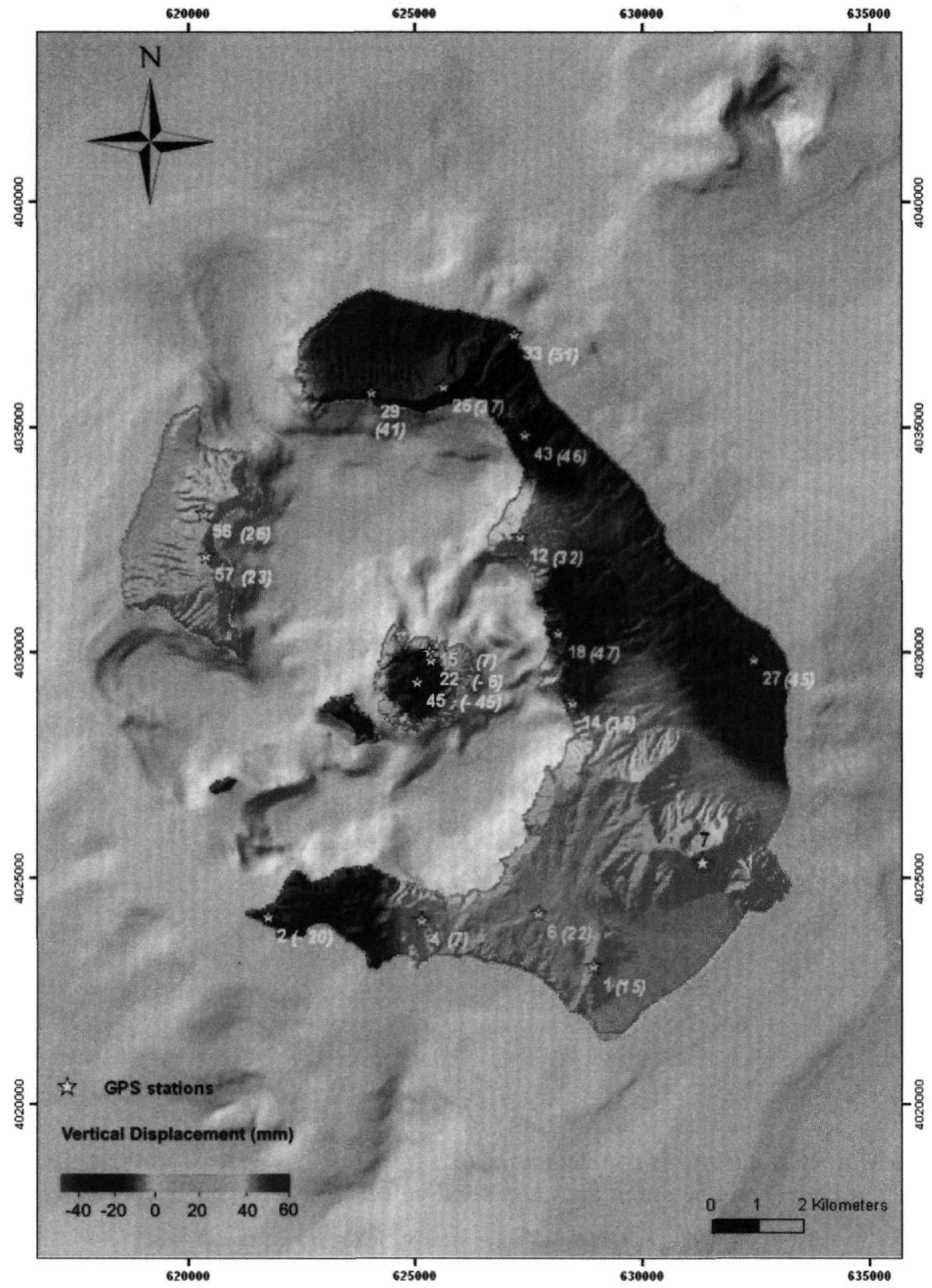

Figure 4 - Map of Vertical Displacement of Santorini. Values in the parenthesis represent the vertical displacement in $\mathbf{m m}$ 


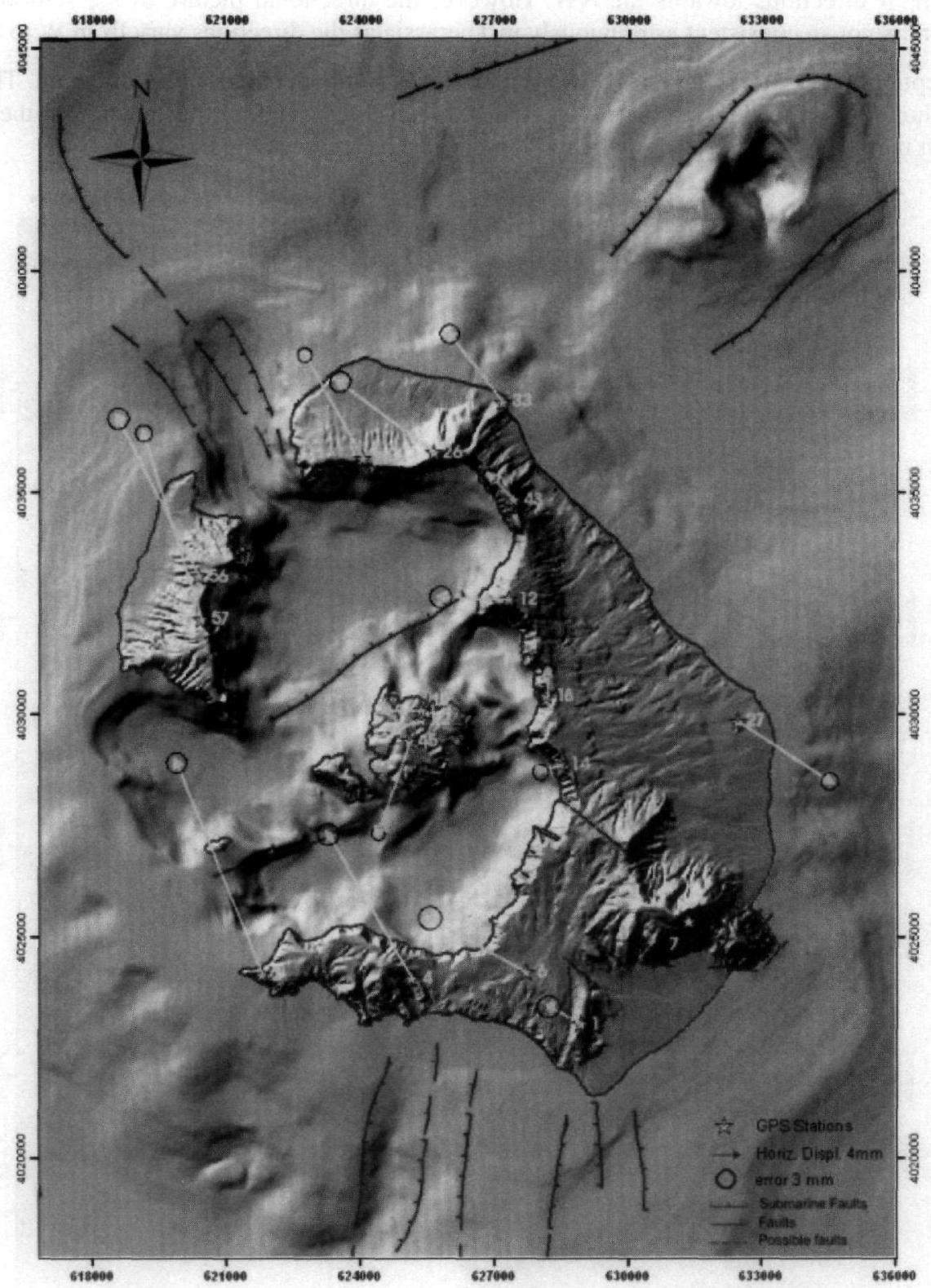

Figure 5 - Map of Horizontal Displacements of Santorini. The arrows indicate the horizontal displacements which are calculated with reference to GPS station 7

\section{Discussion \& Conclusions}

The GPS method was proved to be a useful tool for the determination of the ground deformation in various volcanic centers (Nishi et al. 1999, Owen et al. 2000, Sturkell and Sigmundsson 2000, Kariya et al. 2000, Lagios 2000, 2005, Borgström et al. 2004, Ukawa et al. 2006). The volcanic activity of the Santorini Island System is expected to be associated with ground deformation phenomena, such as uplift and subsidence. 
It was found that in the region of the Kammeni Islands during the period 1994-2005, subsidence was observed of at least $45 \mathrm{~mm}$, including the SW part of Thera, around the area of Faros, with 20 $\mathrm{mm}$ amplitude of subsidence. The rest of the study area showed a general uplift with values ranging from 10-51 mm. During the same period, the horizontal displacements vary between 4-37 $\mathrm{mm}$, and their directions seem to correlate with the subsidence in the caldera (deflation) and a probable inflation around the area of the Columbo Volcano. The Santorini volcanic edifice as being dominated by an active extensional regime (Papazachos and Kiratzi 1996) seems to be strongly affected by the Kammeni and Columbo major tectonic faulting features, whose role and activity should have largely contributed to the observed subsidence and uplift in the area.

The uplift observed on both stations in Therassia and the subsidence noticed generally in Nea Kammeni have resulted in an increase of the baseline length between the stations of these areas by 26-30 $\mathrm{mm}( \pm 10 \mathrm{~mm})$. This is consistent with earlier EDM work by Stiros el al. (2005) for the same area between Therassia and Nea Kammeni.

The change of direction of the horizontal component of all stations at the northern part of Thera should have been influenced by the presence of the Columbo fault zone, suggesting a major tectonic component, differentiating the motions of displacement across this zone.

The uplift generally observed at the half northern part of Thera is consistent with earlier microgravimetric studies (Lagios 1995), where this area has shown a tendency to uplift for the period 1984-1991.

\section{References}

Angelier, J., Lyberis, N., Le Pichon, X., Barrier, E., and Huchon, P., 1982. The tectonic development of the Hellenic arc and the Sea of Crete: a synthesis, Tectonophysics, 86, 159196.

Borgstrom, S., Casu, F., Del Gaudio, C., De Martino, P., Euillades, P.A., Grosse, P., Manzo, M., Ricciardi, G.P., Ricco, C., Siniscalchi, V., Zeni, G., and Lanari, R., 2004. Geodetical monitoring of the Phlegrean Volcanic District (Naples, Italy), $5^{\text {th }}$ International Symposium on Eastern Mediaterranean Geology, Thessaloniki, Greece, 14-20 April 2004, 678-681

Giannopoulos, J., Lagios, E., and Sigmundsonn, F., 1996. Global Positioning System (GPS) Monitoring on Santorini (Thera) Volcano, Proc. 2nd Workshop on European Laboratory Volcanoes, May 2-4, Santorini, Greece (Publ. Europ. Comm. DGXII Environment and Climate Res. Progr.), 271-279.

Heiken, G., and McCoy, F., 1984. Caldera development during the Minoan eruption, Thera, Cyclades, Greece, Journal of Geophysical Research, 89, 8441-8462.

Jackson, J.A., 1994. Active tectonics of the Aegean region, Annual Reviews of Earth and Planetary Sciences, 22, 239-271.

Kariya, S., Kimata, F., Watanabe, H., Oikawa, J., and Matsushima, T., 2000. Ground deformation inferred from GPS observation in Miyakejima Volcano, Geodetic Society of JPN, 94th Meeting Program and Abstract, 43p.

Lagios, E., 1995. High Precision study of gravity variations over Thera Volcano, Greece, Tiré à part des Cahiers du Centre Européen de Géodynamique et de Séismologie, 8, 293-305.

Lagios, E., 2000. Intense crustal deformation rates on Nisyros Island (Greece), deduced from GPS studies, may foreshadow a forthcoming volcanic event. In S. Balassanian et al. (ed.), Proc. 2nd Intern. Conf. on Earthquake Hazard \& Seismic Pisk Reduction, Kluwer Academic Publishers, 249-259pp. 
Lagios, E., Sakkas, V., Parcharidis, Is., and Dietrich, V., 2005. Ground deformation of Nisyros Volcano (Greece) for the period 1995-2002: Results from DInSAR and DGPS observations, Bull Volcanol., 68, 201-214.

Le Pichon, X., and Angelier, J., 1979. The Hellenic Arc and trench system: a key to the Neotectonic evolution of the Eastern Mediterranean area, Tectonophysics, 60, 1-42.

LEICA Geo Office 2004, v. 1.1, LEICA Geosystems AG., CH-9435 Heerbrugg, Switzerland.

McKenzie, D.P., 1970. Plate tectonics of the Mediterranean region, Nature, 226, 239-243.

McKenzie, D.P., 1972. Active tectonics of the Meditteranean region, Geoph. J. Astron. Soc., 30, 109-185.

Mercier, J. L., Sorel, D., and Vergely, P., 1989. Extensional tectonic regimes in the Aegean basins during the Cenozoic, Basin Research, 2, 49-71.

Nishi, K., Ono, H., and Mori, H., 1999. Global positioning system measurements of ground deformation caused by magma intrusion and lava discharge: the 1990-1995 eruption at Unzendake Volcano, Kyushu, Japan, J. Volcanol. Geotherm. Res., 89, 23- 34.

Owen, S., Segall, P., Lisowski, M., Miklius, A., Denlinger, R., and Sako, M., 2000. Rapid deformation of Kilauea volcano: GPS measurements between 1990 and 1996, J. Geophys. Res., 105, 18,983-18,998

Papazachos, B.C., and Comninakis, P.E., 1971. Geophysical and tectonic features of the Aegean arc, J. Geophys. Res., 76, 8517-8533.

Papazachos, B.C., and Kiratzi, A., 1996. A detailed study of the active crustal deformation in the Aegean and surrounding area, Tectonophysics, 253, 129-153.

Papazachos, B.C., Papadimitriou, E.E., Kiratzi, A.A., Papazachos, C.B., and Louvari, E.K., 1998. Fault plane solutions in the Aegean Sea and the surrounding area and their tectonic implications, Bollettino di Geofisica Teoretica ed Applicata, 39, 199-218.

Pichler, H., and Kussmaul, S., 1980. Comments on the geological map of the santorini islands. In: Doumas, C. (ed.) Thera and the Aegean World II. The Thera Foundation, London, 413-427.

Piper, D.J.W., Pe-Piper, G., Perissoratis, C., and Anastasakis, G., 2004. Submarine rocks around Santorini and their relationship to faulting. 5th International Symposium on Eastern Mediterranean Geology, Thessaloniki, Greece, 873-876.

Rothacher, M., Beutler, G., Gurtner, W., Brockmann, E., and Mervart, L., 1993. Bernese GPS Software Documentation version 3.4., Astronomical Institute, University of Berne, Switzerland.

Stiros, S., Chasapis, A., and Kontogianni, V., 2005. Geodetic evidence for slow inflation of the Santorini caldera, Developments in Volcanology, 7, 205-210.

Sturkell, E., and Sigmundsson, F., 2000. Continuous deflation of the Askja caldera Iceland, during the 1983-1998 non-eruptive period, J. Geophys. Res., 105, 25671-25684. 